\title{
Murine leukemia virus targets innate-like B1 B cells to establish infection in mice
}

\author{
Xaver Sewald", Christin Herrmann, Fei Li, Walther Mothes \\ From Frontiers of Retrovirology: Complex retroviruses, retroelements and their hosts \\ Cambridge, UK. 16-18 September 2013
}

\section{Background}

Retroviruses are believed to efficiently spread via sites of cell-cell contact designated virological synapses. This model was developed based on in vitro evidence in which infected cells establish cell-cell contact with uninfected cells. Applying intravital microscopy, we were recently able to provide in vivo support for the existence of virological synapses within the lymph node of living mice. Visualizing cells infected with fluorescently labeled murine leukemia virus (MLV) we identified B cells that were able to form long-lived virological synapses with uninfected lymphocytes [1]. In vivo virological synapses were, like their in vitro counterpart, dependent on the expression of the viral envelope glycoprotein (Env) and characterized by a prolonged polarization of viral capsid to the cell-cell interface. B cells were among the first cells to become infected by incoming MLV. However, the specific subtype of B cells that is susceptible to MLV had remained unknown.

\section{Results}

Here we present evidence for a critical role of innate-like $\mathrm{B} 1 \mathrm{~B}$ cells in the establishment of MLV infection in mice. Adoptively transferred B1 B cells are selectively targeted by MLV. Mice lacking B1 B cells are resistant to MLV infection. In addition, using knockout mice we provide evidence for the contribution of adhesion factors expressed by B1 B cells in spreading of retroviruses in vivo.

\section{Conclusions}

Our work reveals the critical importance of a distinct $B$ cell subset in the susceptibility to retroviral infections under physiological conditions in vivo.

\footnotetext{
Yale University, Department of Microbial Pathogenesis, New Haven, CT
} 06536, USA

C 2013 Sewald et al; licensee BioMed Central Ltd. This is an Open Access article distributed under the terms of the Creative Commons Attribution License (http://creativecommons.org/licenses/by/2.0), which permits unrestricted use, distribution, and reproduction in any medium, provided the original work is properly cited.
Published: 19 September 2013

\section{Reference \\ 1. Sewald X, Gonzalez DG, Haberman AM, Mothes W: In vivo imaging of virological synapses. Nature Communications 2012, 3:1320.}

doi:10.1186/1742-4690-10-S1-P84

Cite this article as: Sewald et al:: Murine leukemia virus targets innate-like B1 B cells to establish infection in mice. Retrovirology 2013 10(Suppl 1):P84.
Submit your next manuscript to BioMed Central and take full advantage of:

- Convenient online submission

- Thorough peer review

- No space constraints or color figure charges

- Immediate publication on acceptance

- Inclusion in PubMed, CAS, Scopus and Google Scholar

- Research which is freely available for redistribution 